\begin{tabular}{c} 
Volume and Issues Obtainable at Center for Sustainability Research and Consultancy \\
Journal of Accounting and Finance in Emerging Economies \\
ISSN: 2519-0318 ISSN (E) 2518-8488 \\
Volume 5: Issue 1 June 2019 \\
CSRᄃ \\
Journal homepage: www.publishing.globalcsrc.org/jafee \\
\hline
\end{tabular}

\title{
The Interaction Effect of Financial Leverage on the Relationship Between Board Attributes and Firm Performance; Evidence of Non-financial Listed Companies of Pakistan
}

\author{
${ }^{1}$ Sajjad Nawaz khan, ${ }^{2}$ Muhammad Noman, ${ }^{3}$ Fakhra Mustafa, ${ }^{4}$ Sidra Abbasi \\ ${ }^{1}$ School of Accountancy (UUM), Malaysia, Sajjadnawazkhan2015@gmail.com \\ ${ }^{2}$ Ph.D. Scholar, (UUM), Malaysia, naumanyasin@ ciitvehari. edu.pk, \\ ${ }^{3}$ MS. Business administration (NCBA), Multan, Pakistan, fmustafa.087@gmail.com \\ ${ }^{4}$ MS. Business administration (NCBA), Multan, Pakistan, sidra.abbasi@cps.ucp.edu.pk
}

\begin{tabular}{|c|c|}
\hline ARTICLE DETAILS & ABSTRACT \\
\hline History & \multirow{7}{*}{$\begin{array}{l}\text { The eminence of corporate governance (CG) was grasped after the major } \\
\text { blunders in corporate strategies and distinct corporate scandals around the } \\
\text { world during the global financial crises. Advanced countries have passed } \\
\text { numerous laws such as "Say on Pay" or the Sarbanes-Oxley Act to shield } \\
\text { the shareholder's wealth. However, the evolving countries are still } \\
\text { flourishing to gain recognition in corporate governance (CG) } \\
\text { effectiveness. The intention of the study is to probe the link between the } \\
\text { CG (board size, outside directors) and firm performance (Tobin's Q). } \\
\text { Leverage has been used as interaction term in current study. The data had } \\
\text { been collected from } 130 \text { non-financial firms from the year } 2012 \text { to } 2015 \\
\text { and Multiple Regression Techniques will be use as the instruments for } \\
\text { data analysis. The results indicate that the board size and Tobin's Q have a } \\
\text { significant association and outside directors' insignificant association with } \\
\text { Tobin's Q. The interaction effect of leverage found a significant } \\
\text { connotation between board size, outside directors, and Tobin's Q. }\end{array}$} \\
\hline Revised format: May 2019 & \\
\hline Available Online: June 2019 & \\
\hline Keywords & \\
\hline Leverage, Board Size, Outside & \\
\hline Directors, Performance & \\
\hline $\begin{array}{l}\text { JEL Classification: } \\
G 31, G 39\end{array}$ & \\
\hline
\end{tabular}

(C) 2019 The authors, under a Creative Commons Attribution-Non

Commercial 4.0

Corresponding author's email address: Sajjadnawazkhan2015@gmail.com

Recommended citation: khan, S. N., Noman, M., Mustafa, F. and abbasi, S. (2019). The Interaction Effect of Financial Leverage on the Relationship Between Board Attributes and Firm Performance; Evidence of Nonfinancial Listed Companies of Pakistan. Journal of Accounting and Finance in Emerging Economies, 5 (1),

115-122

DOI: $10.26710 /$ jafee.v5i1.681

\section{Introduction}

Performance of firms is dynamic significance for economic development of stakeholders and investors. Investors need a high return on their investment and well-organized business that could bring long-term profits for its stakeholders. Despite the extensive academic literature on the bases of firm performance, still researchers are struggling to evaluate the determinants of firm performance in both advanced and emerging economies (Cinca, Molinero, \&Larraz, 2005; Delen, Kuzey, \& Uyar, 2013; Galbreath \& Galvin, 2008; Gombola \& Ketz, 1983; Hawawini, Subramanian, \&Verdin, 2003; Ho \& Wu, 2006). As per as the current literature is concerned, researchers have evaluated several factors that could have an impact on the firm performances. For instance, pertaining the developed economies, there are certain factors such as employee ownership (Kim \& Patel, 2017), 
marketing capabilities (Cacciolatti \& Lee, 2016), stakeholder relationships and brand equity (Wang \& Sengupta, 2016), these could positively or negatively influence a firm performance. On the other hand, developing countries are still focusing on issues such as the industry and governance diversity (Chen \& Lin, 2016), capital structure (Iavorskyi, 2013), corporate governance (CG) (Arora \& Sharma, 2016, khan \& Ali, 2018), tangibles and intangibles (Lazăr, 2016) that could possibly influence a firm performance. In the specific context of Pakistan, previous studies identified that risk management, capital structure, CG and economic indicators could likely influence a firm performance of Pakistani capital market (Mirza \& Javed 2013; khan \& Ali, 2017). The business of Pakistan particularly industrial sectors is frequently facing low performance in a textile sector, cement, and shoe. This is leading to a feeble economy and poor firms' performance which is eventually affecting the foreign investors to invest in Pakistan. Consequently, multinational corporations are unwilling to commence their corporate operations in Pakistan (Shaikh, 2013). Reports to CIA (2016), Pakistan industrial production growth in 2016 is $6.8 \%$, still behind the production growth rate of $8.00 \%$ in 2007. Moreover, according to ICMAP (2015), the industrial sector of Pakistan is facing abounding issues like power and energy crises, lack of investment, high production cost, and weak governance cooperation. Due to all these factors, the industrial sectors are facing huge losses of about USD 3.81 billion. This amount is almost $15 \%$ of the total revenues of government.

As per above discussion which indicates the issues of the performance due to different factors like capital structure and CG etc. Nowadays, CG has attended more intention in the current business scenario all over the world particularly due to the corporate scams and the failures of firms all around the globe. Accountability and transparency became important for the investor's attraction and one hand capital funds and on the other hand, need financial security and stability. Recent business environment is very viable, the ambiguity and risk are the foremost features of the current business. The modern business environment becomes very tough to control and predict (Kuratko \& Morris, 2003). Strong CG can be the best solution to lessen the risk and uncertainty in the current business scenarios. Moreover, decreasing the risk level can attract investors. It is usually supposed that good CG improves performance of the firm and provides protection to shareholders, interest. The most important role of a sound CG exercise will provide better link between the firms and its environment and shelter its important resources through appealing the capital funds and investors. Moreover, the sound CG exercise can be a real tool for the organization to attain better performance. In addition, sound corporate CG carries good management and better utilization of the firm resources which can significantly contribute to the firm value (Keong, 2002). Therefore, it is important to understand the link between CG and firm performance. Past studies found the inclusive results in the relationship between CG and firm performance. Most of earlier studies has been conducted related to CG in advanced countries but less attention was given to the emerging economies countries like Pakistan. This means that there is a need for such research. One of the vital confrontations in the corporate of sector of Pakistan is that of CG. Previous studies in Pakistan, however, revealed that Pakistan still has a weak CG structure (Ameer, 2013; Batool \& Javid, 2014, Khan \& Ali, 2017). The main aim of the current study is to test whether internal CG such as board size, outside directors influence the performance of Pakistani firm and also to check the interaction effect of leverage between them.

The following are the research objectives:

a) To test the link between board size and firm performance in listed firms on Pakistan Stock Exchange year, 2012 to 2015

b) To test the link between outside directors and firm performance in listed firms on Pakistan Stock Exchange year, 2012 to 2015

c) To test the interactional effect of leverage on the relationship between board attributes (board size and outside directors,) and firm performance in the listed firm Pakistan Stock Exchange year, 2012 to 2015.

The concern of the current study is to emphasize the significance of leverage as possible description of interaction in strengthening or weakening the influence of $\mathrm{CG}$ on firm performance, particularly in the underdeveloped countries firms.

\section{Framework of the Study}

The research framework of the present study is a sprout of the Hsu (2013)., Khan, and Ali, (2017)., and Chen \& Lin, (2016). is demonstrated in Figure 1. 


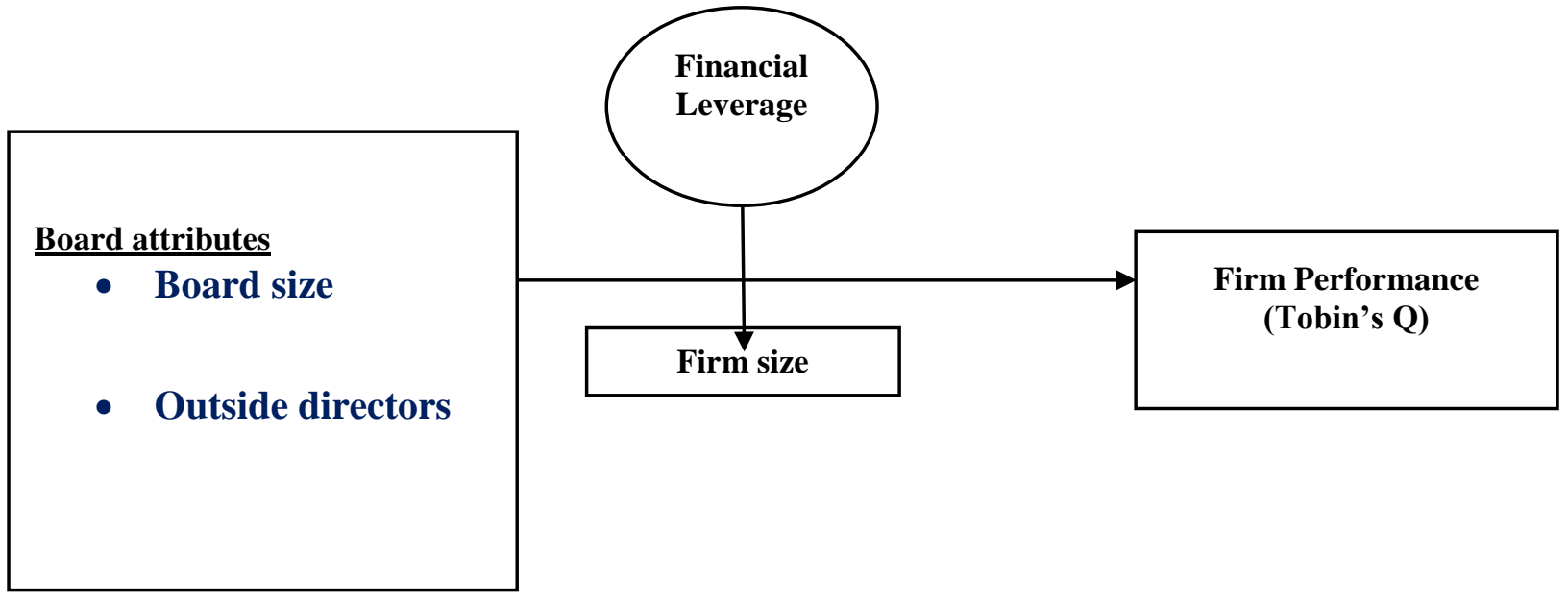

Figure 1; Conceptual Frame Work

Source; Shleifer and Vishny (1997); Hsu (2013)., Khan, and Ali, (2017)., Chen \& Lin, (2016)

\section{Literature Review and Hypotheses Development of the Study}

Agency theory based upon the assumption that both agent and principal interest changes, and principal can reduce the gap of concern by offering maximum incentives to the agent also meet them to keep an eye on the agent (Ntim \& Oseit, 2011; Khan \& Ali 2017). A principal should take every measure to avoid agency issue (Bonazzi\& Islam 2007) and established the board of directors conflicting aspects of the management can aid to achieve the aim of superb governance and convincingly affect firm performance.

Board activities are profoundly reliant on agency theory, as time passes, researches on the effects of CG and firm performance have been increased due to the realization of the importance of CG. Current literature is diverse and no consensus among the researchers concerning the outcome (Mayur \& Saravanan, 2017; Black, Jang, \& Kim (2006). Most of the prior studies reported that CG has an influence on firm performance for updated technology ventures and supported the relevant relationships among the CG. In addition, some of the previous studies reported the significant relationship CG and firm performance whose research was carried on the listed firm of Pakistan stock exchange (PSX) (Khan \& Ali 2018; Akbar 2014).

Moreover, board of directors two most imperative functions are monitoring and advising (Raheja 2005; Adams \& Ferreira 2007) and performed by inside and outside directors, though Fama and Jensen (1983) indicates the value of outside directors, who bring valued expertise and possibly important contacts. The benefit of higher board size is the superior collective information that the board afterward possesses, and hereafter higher boards will lead to greater performance (Dalton \& Co-workers 1999, 2005).

Previous literature shown that the board size of the directors plays a vibrant role in the managements' ability to oversee managers (Anderson, Mansi \& Reeb 2004). According to Khan \& Ali (2018), the link between the board size and performance is positive. Similarly, Coles, Daniel, \& Naveen (2008) reported that performance gets better with board size for complicated companies. Some of the previous studies that reveal the negative link between the board size and performance include Mayur \& Saravanan, (2017). Mashayekhi and Bazaz (2008) found an no link between board size and performance of Irani companies.

On the other side, the position of outside directors is associated to their capability to evaluate the performance of the firm independently. The directors have valued knowledge about firms activates that works inside the firm, while outside directors can contribute objectivity and expertise in evaluating manager's decisions. Therefore, large board independence permits non-executives directors to monitor a firm more strictly and take accurate actions. In addition to that, according to Brickley, and James (1987), the presence of outside directors contributes to reduction managerial consumption of perquisites. However, the results of the current academic literature on the empirical link 
between outside directors and firm performance are also mixed. For instance, Kouki and Guizani (2015), a study 42 non-financial Tunisian firms over the period of 2004-2010 and they found a positive link between independent directors and firm performance. Mohapatra (2016) found that outside directors have an insignificant relationship with operating performance. Johl et al. (2015) also found an no link of board independence with firm performance in the Malaysian context. The current literature indicates the inconsistency or mixed results of board size and outside directors with performance. Therefore, firstly, the current study sees the effect of board size and outside directors on firm performance and secondly employee; the moderator was taken as leverage which was also been employed (Azeem, Hassan, \& Kouser, 2013).

H1: Board size have a significant influence on firm performance.

$\mathrm{H} 2$ : Outside directors have a significant influence on earnings firm performance

H3: Leverage moderates the link between board size, outside directors and firm performance

\subsection{Control Variable}

Most of the previous studies used firm size as a control variable in estimating the link between the CG and firm performance. A study by Ehikioya (2009) found a positive association between firm size and firm performance. On the other side, Mohd Ghazali (2010) reported that firm size is negatively related to performance.

\section{Methodology of the Study}

\subsection{Sample of the Study}

The total population of the current study incorporates the non-financial listed firm on the Pakistan stock exchange year, 2012 to 2015. A total of 130 firms serves as a sample out of 384 non-financial firms. The data of the variables collected through the annual reposts or state bank of Pakistan website.

\subsection{Measurement of the variables}

Table 1; Description of used variables

\begin{tabular}{|l|l|}
\hline Variables & Measurement \\
\hline Board size & "Total number of directors on the board" \\
\hline Outside directors & "The total number of outside non-executive directors/ total number of directors" \\
\hline $\begin{array}{l}\text { Leverage } \\
\text { Firm size }\end{array}$ & $\begin{array}{l}\text { "Total liabilities/ total assets" } \\
\text { "Natural log of total assets" }\end{array}$ \\
\hline Tobin's Q & $\begin{array}{l}\text { "Total asset + market value of equity - book value of equity - deferred taxes } \\
\text { /Total assets" }\end{array}$ \\
\hline
\end{tabular}

\subsection{Model Specifications}

TobinQit $=\alpha+\beta 1(B D S Z i t)+\beta 2($ OSDZit $)+\beta 2\left(L E V^{*} B D S i t\right)+\beta 3(F S)+\varepsilon i t \ldots$

\subsection{Descriptive Analysis}

Table 2

\begin{tabular}{|l|l|l|l|l|}
\hline Variables & Mean & Std.dv & Maximum & Minimum \\
\hline Board size & 8.04 & 1.33 & 07 & 15 \\
\hline Outside directors (\%) & 0.15 & 0.14 & 0 & 77 \\
\hline Leverage & 1.34 & 13.25 & 0.0008 & 298.27 \\
\hline Tobins' Q & 0.57 & 1.23 & 0.003 & 22.07 \\
\hline
\end{tabular}

The above table 2 indicates the descriptive statistics which shows that the board size (BS) average value is 8.04, the minimum value is 07 and the maximum value is 15 . Outside directors (OSD) average value is 0.15 and maximum 0 value and minimum value. The mean value of leverage is 1.34 and maximum value is 2.98 and minimum value is 0.0008 . 
4.5 Diagnostic tests

\subsubsection{Multicollinearity Testing}

The multilinearity test to displays Variance Inflation Factor (VIF) value of every independent variable as shown in Table 3

Table 3

\begin{tabular}{|c|c|c|}
\hline Variables & VIF & 1/VIF \\
\hline BS & 1.12 & 0.89 \\
\hline OD & 1.12 & 0.89 \\
\hline FS & 1.10 & 0.91 \\
\hline
\end{tabular}

The results indicate that every independent variable have a tolerance value is less 0.10 and VIF is less 10 . Consequently, it can be determined that the independent variables can used in the regression model of current research are free the issue of multicollinearity (Gozali, 2013)

\subsubsection{Autocorrelation Testing}

To determine the autocorrelation, using the Wooldridge test, the results of table 4 indicates that there is no autocorrelation problem exists.

Table 4: Wooldridge test

\begin{tabular}{|l|l|}
\hline $\mathrm{F}(1,129)$ & P-Value \\
\hline 1.88 & 0.172 \\
\hline
\end{tabular}

\subsubsection{Heteroscedasticity Testing}

To determine the heteroscedasticity test, use the Breusch-pagan test/Cook-Weisberg test. the results of the table 5 indicate the no problem of heteroscedasticity.

Table 5: Breusch-pagan test/Cook-Weisberg test

\begin{tabular}{|c|c|}
\hline $\mathrm{Ch}^{2}(1)$ & P-Value \\
\hline 705.54 & 0.354 \\
\hline
\end{tabular}

\subsection{Regression Analysis}

Table 6

\begin{tabular}{|l|l|l|l|}
\hline Variables & Coff & t-value & P-value \\
\hline Tobins' Q & & & \\
\hline Board size (BS) & 0.12 & 2.97 & 0.003 \\
\hline Outside directors (OD) & 1.15 & 1.55 & 0.121 \\
\hline Leverage (LEV) & 0.87 & 1.86 & 0.056 \\
\hline BS*LEV & .060 & 3.96 & 0.000 \\
\hline OD*LEV & -0.21 & -3.99 & 0.000 \\
\hline Firm size (FS) & 0.028 & 0.48 & 0.631 \\
\hline constant & -.8631597 & -2.45 & 0.015 \\
\hline R2 & 0.067 & & \\
\hline F-value & 5.91 & & \\
\hline Prob > chi2 & 0.0000 & & \\
\hline
\end{tabular}




\section{Findings and Discussion}

\subsection{Board Size, Outside Directors, Leverage and Firm Performance}

the table 6 showing the results of regression analysis and indicating the board size (BS) has positive significant effect $(\beta=0.12, \mathrm{t}=2.97, \mathrm{P}<0.01)$ on firm performance (Tobin's' $\mathrm{Q}$ ). The current study indicates that the board size plays a significant role in the management ability to oversee managers. This result is consistent with previous studies such as (Khan \& Ali 2018; Sheikh, Wang and Khan 2013; Malik et al. 2014; Johl, 2015). Outside directors have insignificant effect $(\beta=0.1 .15, \mathrm{t}$ value $=1.55, \mathrm{p}>0.1)$ on firm performance (Tobin's' $\mathrm{Q})$. Outside directors shows no relation with firm performance due to low representation of non-executive directors. This finding is in line prior studies such as (Johl et al. 2015, Sheikh, Wang and Khan 2013). The leverage also shows an interaction effect between board sizes, outside directs and firm performance. The findings are supporting the view of Hsu (2013) that leverage is very important to firms so as to ensure the financial resources required for new business actives and get the better performance of the firm.

\section{Conclusion and Implication}

The intention of current study is to offers empirical evidence of the interaction effect of leverage on the relationship between board size, outside directors and firm performance. The finding of the study suggests that interaction of leverage strengthen the influence of board size and outside directors on firm performance.

The current study results have the potential to support institution such as Pakistan Stock Exchange and invertors to know how to leverage can influence performance of firms. Also, the results of this study provide the better understanding of agency theory as well as the influence of the agency theory.

\section{References}

Ahmed Haji, A., \& Anum Mohd Ghazali, N. (2013). The quality and determinants of voluntary disclosures in annual reports of Shari'ah compliant companies in Malaysia. Humanomics, 29(1), 24-42.

Ameer, B. (2013). Corporate governance-issues and challenges in Pakistan.International Journal of Academic Research in Business and Social Sciences, 3(4), 79

Anderson, R. C., Mansi, S. A., \& Reeb, D. M. (2004). Board characteristics, accounting report integrity, and the cost of debt. Journal of accounting and economics, 37(3), 315-342.

Arora, A., \& Sharma, C. (2016). Corporate governance and firm performance in developing countries: evidence from India. Corporate Governance, 16(2), 420-436.

Azeem, M., Hassan, M., \& Kouser, R. (2013). Impact of Quality Corporate Governance on

Firm Performance: A Ten Year Perspective. Pakistan Journal of Commerce \& Social Sciences, 7(3).Management, 3(2).

Batool, Z., \& Javid, A. Y. (2014). Dividend policy and role of corporate governance in manufacturing sector of Pakistan. Pakistan Institute of Development Economics, (2014), 109.

Black, B. S., Jang, H., \& Kim, W. (2006). Does corporate governance predict firms' market values? Evidence from Korea. The Journal of Law, Economics, and Organization, 22(2), 366-413.

Bonazzi, L., \& Islam, S. M. (2007). Agency theory and corporate governance: A study of the effectiveness of board in their monitoring of the CEO. Journal of Modelling in Management, 2(1), 7-23.

Brickley, J. A., \& James, C. M. (1987). The takeover market, corporate board composition, and ownership structure: The case of banking. The Journal of Law and Economics, 30(1), 161-180.

Cacciolatti, L., \& Lee, S. H. (2016). Revisiting the relationship between marketing capabilities and firm performance: The moderating role of market orientation, marketing strategy and organisational power. Journal of Business Research, 69(12), 5597-5610.

Chen, C. J., \& Lin, Y. H. (2016). Managing the foreign investment portfolio: How industry and governance diversity influence firm performance. International Business Review, 25(6), 1235-1245.

CIA (2016). The World Fact book. Retrieved from https://www.cia.gov/llibrary/publications/the-worldfactbook/fields/2016.html

Cinca, C. S., Molinero, C. M., \& Larraz, J. G. (2005). Country and size effects in financial ratios: A European perspective. Global Finance Journal, 16(1), 26-47 
Coles, J. L., Daniel, N. D., \& Naveen, L. (2008). Boards: Does one size fit all?. Journal of financial economics, 87(2), 329-356.

Delen, D., Kuzey, C., \& Uyar, A. (2013). Measuring firm performance using financial ratios:

A decision tree approach. Expert Systems with Applications, 40(10), 3970-3983.

Detthamrong, U., Chancharat, N., \& Vithessonthi, C. (2017). Corporate governance, capital structure and firm performance: evidence from Thailand. Research in International Business and Finance, 42, 689-709.

Ehikioya, B. I. (2009). Corporate governance structure and firm performance in developing economies: evidence from Nigeria. Corporate Governance: The international journal of business in society, 9(3), 231-243.

Galbreath, J., \& Galvin, P. (2008). Firm factors, industry structure and performance variation: New empirical evidence to a classic debate. Journal of business research, 61(2), 109-117.

García-Meca, E., García-Sánchez, I. M., \& Martínez-Ferrero, J. (2015). Board diversity and its effects on bank performance: An international analysis. Journal of Banking \& Finance, 53, 202-214.

Gombola, M. J., \& Ketz, J. E. (1983). Financial ratio patterns in retail and manufacturing organizations. Financial Management, 12(2), 45-56.

Hansen, G. S., \& Wernerfelt, B. (1989). Determinants of firm performance: The relative importance of economic and organizational factors. Strategic management journal, 10(5), 399-411.

Hawawini, G., Subramanian, V., \& Verdin, P. (2003). Is performance driven by industry-or firm-specific factors? A new look at the evidence. Strategic management journal, 24(1), 1-16.

Ho, C. T., \& Wu, Y. S. (2006). Benchmarking performance indicators for banks. Benchmarking: an international journal, 13(1/2), 147-159.

Iavorskyi, M. (2013). The impact of capital structure on firm performance: evidence from ukraine (Doctoral dissertation, Kyiv School of Economics).

ICMAP (2015). Proposed Strategy for Economic and Industrial Growth of Pakistan, Research \& Publications Department, ICMA Pakistan, Karachi.

Johl, S. K., Kaur, S., \& Cooper, B. J. (2015). Board characteristics and firm performance: evidence from Malaysian public listed firms. Journal of Economics, Business and Management, 3(2).

Kalirajan, K., \& Singh, K. (2009). The Impact of Globalization on Employment Generation in India: The case of emerging' Big Shopping Malls and Retailers'. The Foundation for Advanced Studies on International Development in Tokyo.

Keong, L. C. (2002). Introduction-The corporate governance debate. Corporate governance: An Asia-Pacific critique. Hong Kong: Sweet \& Maxell Asia.

Khan, S. N., \& Ali, E. I. E. (2017). How Intellectual Capital Moderates the Relationship between Corporate Governance and Firm Performance in the Capital Market of Pakistan: A Conceptual Review and Proposal. Journal of Economic \& Management Perspectives, 11(2), 359-371.

KHAN, S. N., \& Ali, E. I. E. (2018). The Influence of Corporate Governance on Firm Performance; Empirical Evidence from Pakistan. Asian Journal Of Multidisciplinary Studies, 6(5).

Kim, K. Y., \& Patel, P. C. (2017). Employee ownership and firm performance: A variance decomposition analysis of European firms. Journal of Business Research, 70, 248-254.

Kouki, M., \& Guizani, M. (2015). Outside Directors and Firm Performance: The Moderating Effects of Ownership and Board Leadership Structure. International Business Research, 8(6), 104-116.

Kuratko, D. F., \& Morris, M. H. (2003). Corporate entrepreneurship: The dynamic strategy for 21st century organizations. In Issues in Entrepeneurship (pp. 21-46). Emerald Group Publishing Limited.

Kyereboah-Coleman, A. (2007). Corporate governance and shareholder value maximization: An African perspective. African Development Review, 19(2), 350-367.

Lazăr, S. (2016). Determinants of Firm Performance: Evidence from Romanian Listed Companies. Review of Economic and Business Studies, 9(1), 53-69.

Liao, C. H., \& Hsu, A. W. H. (2013). Common membership and effective corporate governance: Evidence from audit and compensation committees. Corporate Governance: An International Review, 21(1), 79-92. 
Makki, M. A. M., \& Lodhi, S. A. (2014). Impact of Corporate Governance on Intellectual Capital Efficiency and Financial Performance. Pakistan Journal of Commerce \& Social Sciences, 8(2).

Malik, M., Wan, D., Ahmad, M. I., Naseem, M. A., \& Rehman, R. U. (2014). Role Of Board Size In Corporate Governance And Firm Performance Applying Pareto Approach, Is It Cultural Phenomena?. Journal of Applied Business Research, 30(5), 1395-1405.

Mashayekhi, B., \& Bazaz, M. S. (2008). Corporate governance and firm performance in Iran. Journal of Contemporary Accounting \& Economics, 4(2), 156-172.

Mayur, M., \& Saravanan, P. (2017). Performance implications of board size, composition and activity: empirical evidence from the Indian banking sector. Corporate Governance: The International Journal of Business in Society, 17(3), 466-489.

Mirza, S. A., \& Javed, A. (2013). Determinants of financial performance of a firm: Case of Pakistani stock market. Journal of economics and International Finance, 5(2), 43-52.

Mohapatra, P. (2016). Board independence and firm performance in India. International Journal of Management Practice, 9(3), 317-332.

Mohd Ghazali, N. A. (2010). Corporate governance and voluntary disclosure in Malaysia. International Journal of Business Governance and Ethics, 5(4), 261-279.

Ngulumbu, O., \& Aduda, J. (2017). Relationship Between Board Composition and Financial Performance of Companies Listed At The Nairobi Securities Exchange. American Journal of Finance, 1(2), 72-90.

Ntim, C. G., \& Oseit, K. A. (2011). The impact of corporate board meetings on corporate performance in South Africa. African Review of Economics and Finance, 2(2), 83-103.

Shaikh, Z.A. (2013). Growing economic problems of Pakistan, Masters Dissertation, Shah Abdul Latif University: Pakistan.

Sheikh, N. A., Wang, Z., \& Khan, S. (2013). The impact of internal attributes of corporate governance on firm performance: evidence from Pakistan. International Journal of Commerce and Management, 23(1), 38-55.

Shleifer, A., \& Vishny, R. W. (1997). A survey of corporate governance. The journal of finance, 52(2), 737-783.

Wang, H. M. D., \& Sengupta, S. (2016). Stakeholder relationships, brand equity, firm performance: A resourcebased perspective. Journal of Business Research, 69(12), 5561-5568. ooperation. South Asia Democratic Forum Working Paper. 